\title{
A socio-economic analysis of Airbnb in New York City
}

Gábor Dudás In recent years, the so-called sharing economy has

Corresponding author: spread all over the world and, through the Institute for Regional Studies,

Centre for Economic and Regional Studies, Hungarian

Academy of Sciences

E-mail:

dudasgabor5@gmail.com

György Vida

Department of Economic and Social Geography, University of Szeged

E-mail:

vidagyorgy.vida@gmail.com

Tamás Kovalcsik

Department of Economic and Social Geography, University

of Szeged

E-mail:

mrkovalcsik@gmail.com

Lajos Boros

Department of Economic and

Social Geography, University

of Szeged

E-mail:

borosl@geo.u-szeged.hu

\section{Keywords:}

Airbnb,

peer-to-peer accommodation,

sharing economy,

New York City, correlation matrix, regression analysis proliferation of online peer-to-peer platforms, provides a marketplace that matches sellers who want to sell/share their underutilised assets with buyers who need them. One of the well-known and heavily debated manifestations of the sharing economy is an accommodation provider platform called Airbnb. Airbnb is experiencing astonishing growth provoking several intense debates, regulatory challenges, and political battles due to its wide-spread effects on rental and real-estate markets. Thus, it is important to analyse the uneven spatial effects of the phenomenon. This paper aims to map Airbnb's presence in New York City but, going beyond visual inspection, it analyses the socio-economic factors influencing the spatiality of Airbnb in the American metropolis. After collecting data from various data sources, we performed a statistical analysis (correlation, regression analysis) to determine the socio-economic conditions of areas and revealed those factors that may affect the spatial distribution of Airbnb listings in the city. Results highlight that (1) Airbnb supply concentrates in those parts of New York City with a young population, (2) there is a significant number of housing units, and (3) the number of points of interest is high.

(n) 


\section{Introduction}

In recent years, the development and diffusion of ICT worldwide alongside the growth of Web 2.0 have facilitated the proliferation of online peer-to-peer (P2P) marketplaces (Einav et al. 2016, Hamari et al. 2016, Ke 2017, Meleo et al. 2016). These platforms are by-products of a larger economic-technological phenomenon called the sharing economy (Hamari et al. 2016, Malhotra-Alstyne 2014, Pizam 2014) also known as collaborative consumption (Botsman-Rogers 2010, Gutiérrez et al. 2016). The phenomenon itself is not new, but the Internet is accelerating its implementation into everyday life as it empowers users to share and make use of underutilised assets and services (Quattrone et al. 2016, Sundararajan 2016) by enabling a match between sellers, who are willing to share their idle capacities and services, and buyers who need them (Azevedo-Weyl 2016, Ke 2017). Services covered by the sharing economy range from transportation (Uber, Lyft, BlaBlaCar) to finance (Kickstarter, Prosper) to accommodation (Airbnb, Couchsurfing, HomeAway); however, P2P marketplaces associated with the sharing economy operate particularly within the field of travel and tourism (Ert et al. 2016). The primary example of this type of marketplace is Airbnb, the best-documented case in P2P accommodation (Oskam-Boswijk 2016). Airbnb describes itself as a 'trusted community marketplace for people to list, discover, and book unique accommodations around the world - online or from a mobile phone or tablet' (Airbnb 2017). In other words, it connects people who have a spare room to rent with guests who need a place to stay (Ke 2017, Quattrone et al. 2016). The company was founded in 2008; since then it has grown exponentially, and now is present in more than 34,000 cities and 191 countries, has more than two million global listings (Airbnb 2017), and surpasses the major hotel chains in accommodation offered and market valuation (Guttentag 2015, Oskam 2016, Oskam-Boswijk 2016, Samaan 2015, Slee 2016). However, the explosive growth of Airbnb has encountered several intense debates, regulatory challenges, and political battles around the world. Advocates of Airbnb argue that it brings many benefits for its users, including extra income, and better resource allocation and utilisation as it enables hosts to become small business owners and reduce their rental burden. Moreover, it also provides new economic activities for cities and municipalities as it fosters tourism because it involves new areas in tourism and deconcentrates the accommodation supply within the city. On the other hand, opponents argue that its negative impacts on cities and residents far outpace its benefits. Detractors state that Airbnb has lost its original objective to be a spare-room sharing platform and highlight the belief that economic self-interest became the main motive rather than sharing ( $\mathrm{Ke} 2017$, Quattrone et al. 2016). The critics also argue that these short-term rentals operate mostly in illegal ways in many cities (Guttentag 2015, Schneiderman 2014, Streitfeld 2014), as hosts may fail to fulfil their tax obligations.

Regional Statistics, Vol. 7. No.1. 2017: 135-151; DOI: 10.15196/RS07108 
Despite the heavy debates around the sharing economy and Airbnb, the phenomenon itself is still too recent for academic literature to have analysed it thoroughly. Papers studying Airbnb and its impacts focus on some key issues such as trust or the reliability of online reviews (Ert et al. 2016, Ikkala-Lampinen 2014, Guttentag 2015, Zervas et al. 2015), quantify the impact of Airbnb on the hotel industry and the local accommodation sector (Choi et al. 2015, Schneiderman 2014, Zervas et al. 2016), or address legal issues surrounding Airbnb (Guttentag 2015, Kaplan-Nadler 2015, McNamara 2015). Moreover, there is a rising interest in the spatial distribution of Airbnb listings in major cities (Dudás et al. 2017, Gutiérrez et al. 2016, Quattrone et al. 2016, Schneiderman 2014) and the socio-economic factors influencing it (Quattrone et al. 2016) to locate those parts of the city that have seen the greatest pressure from Airbnb.

In recent days, Airbnb listings have become globally distributed and reach a fairly heterogeneous coverage; however, focusing on the country level, the main markets are in the US, France, Italy, Spain, and the United Kingdom (Ke 2017). Overall, the US has the most listings and the cities located in the country are considered the main revenue-generating cities of Airbnb with New York City being the most important city of all (Inside Airbnb 2017b).

However, the rapid rise of P2P accommodation rental platforms like Airbnb have profoundly expanded the use of traditional apartments as temporary hotel rooms all over the world, generating public debate about disruptive technologies and their real-world consequences (Schneiderman 2014). The site has run into problem with legislators in several markets, including Amsterdam, Barcelona, Berlin, Los Angeles, etc., although the most important battle that received considerable media attention was in New York between the Attorney General of New York and Airbnb (Slee 2016). As the number of short-term rentals is growing at a staggering pace in New York City, this expansion creates many challenges for communities and legislators throughout the city facing three important issues: violation of $\mathrm{New}$ York City and state laws, significant commercial use, and impact of Airbnb on housing supply and rental prices (Delgado-Medrano-Lyon 2016) as entire homes listed on Airbnb may disappear from the local housing market and drive the rents up (Ke 2017). Several studies were conducted to address these issues and similar ones (Cox-Slee 2016; Delgado-Medrano-Lyon 2016, Samaan 2015, Schneiderman 2014, Waters-Bach 2016) by highlighting the impact of Airbnb on the short-term rental market of New York City. The most frequent question asked by travellers, legislators, and municipalities is where the Airbnb listings are located. Therefore, legislators, planners, and researchers want to reveal the spatial pattern of Airbnb listings and understand the underlying processes affecting the spatial spread of Airbnb more deeply. Thus, the aim of our study is to map Airbnb presence in New York City because there are an abundant number of Airbnb listings in the city, the phenomenon is receiving considerable media attention, and it is in a crossfire of

Regional Statistics, Vol. 7. No.1. 2017: 135-151; DOI: 10.15196/RS07108 
sharing economy criticisms. However, we want to go beyond visual inspection and seek to determine the socio-economic factors influencing the spatiality of Airbnb in the American metropolis. Furthermore, we want to reveal what the main socioeconomic characteristics of areas with Airbnb listings are and where Airbnb customers go.

First, we developed a database that included a large number of Airbnb listings and socio-economic indicators characterising the Neighbourhood Tabulation Areas (NTAs) of New York City, and presented the applied statistical methods. In the second half of the study, the collected data are analysed using correlation matrix and regression analysis, and finally, the key findings are summarised.

\section{Data and methodology}

In order to answer the research question proposed in the previous sections and to conduct a statistical analysis, we needed to collect data from various data sources. On the one hand, we needed detailed data on Airbnb properties, while on the other hand, socio-economic data about the neighbourhoods of New York City.

\section{Airbnb data}

Based on previous studies (Gutiérrez et al. 2016, Inside Airbnb 2017b) we collected a comprehensive set of geolocated Airbnb data from the Inside Airbnb website: http://insideairbnb.com/. Inside Airbnb is an independent initiative and offers Airbnb data for more than 30 major cities around the world. The data represented on the website are publicly available, however, Inside Airbnb states that 'the site is not associated or endorsed by Airbnb or any of Airbnb's competitors' (Inside Airbnb 2017a). The dataset contains information not only about the location (latitude and longitude coordinate) of all Airbnb listings in New York City but also data about the host name and ID, room type, price, minimum nights, number of reviews, listings per host, and availability. The data utilised in this study refer to December 3, 2016, and our dataset contains detailed information about 33,533 distinct hosts and 40,156 listings (Table 1).

Table 1

Descriptive statistics on listings offered by Airbnb in New York City

\begin{tabular}{l|l|c|c|c|c|c}
\hline & & Price & Availability & $\begin{array}{c}\text { Listings } \\
\text { per host }\end{array}$ & $\begin{array}{c}\text { Number } \\
\text { of reviews }\end{array}$ & $\begin{array}{c}\text { Minimum } \\
\text { nights }\end{array}$ \\
\hline & Mean & 207.95 & 143.33 & 1.36 & 15.66 & 4.26 \\
Entire & SD & 234.075 & 145.048 & 1.615 & 26.594 & 16.367 \\
home/apt & Min. & 10 & 0 & 1 & 0 & 1 \\
& Max. & 9,999 & 365 & 28 & 321 & 1,250 \\
\hline
\end{tabular}

(Table continues on the next page.)

Regional Statistics, Vol. 7. No.1. 2017: 135-151; DOI: 10.15196/RS07108 


\begin{tabular}{l|l|c|c|c|c|c}
\hline & & Price & Availability & $\begin{array}{c}\text { Listings } \\
\text { per host }\end{array}$ & $\begin{array}{c}\text { Number } \\
\text { of reviews }\end{array}$ & $\begin{array}{c}\text { Minimum } \\
\text { nights }\end{array}$ \\
\hline \multirow{3}{*}{$\begin{array}{l}\text { Private room } \\
(18876)\end{array}$} & Mean & 89.14 & 164.57 & 2.13 & 15.08 & 3.20 \\
& SD & 151.616 & 151.132 & 1.890 & 29.062 & 7.045 \\
& Min. & 10 & 0 & 1 & 0 & 1 \\
& Max. & 9,999 & 365 & 33 & 380 & 500 \\
\hline \multirow{3}{*}{ Shared room } & Mean & 74.33 & 209.14 & 4.33 & 12.13 & 2.85 \\
$(1374)$ & SD & 280.587 & 149.445 & 5.171 & 22.366 & 7.646 \\
& Min. & 17 & 0 & 1 & 0 & 1 \\
& Max. & 9,900 & 365 & 20 & 284 & 150 \\
\hline \multirow{4}{*}{ Total listings } & Mean & 147.53 & 155.57 & 1.71 & 15.27 & 3.71 \\
& SD & 210.364 & 148.794 & 2.157 & 27.661 & 12.586 \\
& Min. & 10 & 0 & 1 & 0 & 1 \\
& Max. & 9,999 & 365 & 33 & 380 & 1,250 \\
\hline
\end{tabular}

Source: edited by the authors.

\section{Socio-economic data}

To collect the necessary data for the statistical analysis we utilised multiple data sources. Previous studies stated that participation in the sharing economy highly depends on the age of the participants (Eurobarometer 2016, Smith 2016), their ethnic background (Edelman et al. 2016, Schor et al. 2016), level of education (ING 2015, Smith 2016), social status (employment, income) (Schor 2017), and urbanity (Eurobarometer 2016, Smith 2016). Therefore, we took these factors into consideration and our collected data included calculations of demographic information about population density, the number of young and educated people, the percentage of black and non US-born populations, as well as the score for ethnic diversity. The data source was provided by the American Community Survey (ACS) and contained detailed information about the demographic, social, economic, and housing characteristics of New York City (ACS 2017). The ACS is a five-year estimate (2010-2014) aggregated at three geographical levels: boroughs (5), community districts (59), and NTA (195). From this dataset, we queried the necessary data at the NTA level, however, we also collected housing and economic indicators, including indicators of median household income, employment, median gross rent, total housing units, the number of owner-occupied housing units, and housing units with a mortgage. We also gathered points of interest (POI) data to determine the attractiveness of the places. Under this indicator, we can understand hundreds of POI of a varying nature from hospitals to restaurants and hotels. From this database, we selected the relevant categories that may attract the people who use the services offered by Airbnb; thus, we considered POI that fall under one of

Regional Statistics, Vol. 7. No.1. 2017: 135-151; DOI: 10.15196/RS07108 
the following categories: 'eating and drinking', 'attractions', 'retail', and 'sports and entertainment'. The data source for this indicator was the website www.geofabrik.de from which OpenStreetMap data was collected, including 12,999 POI in New York City. Table 2 lists all the indicators utilised in the statistical analysis.

Table 2

Description of variables applied in statistical analysis

\begin{tabular}{|c|c|c|}
\hline Variables & Description & Source \\
\hline abnb_listing & Number of Airbnb listings per km² & Inside Airbnb \\
\hline abnb_price & Average price of Airbnb listings & Inside Airbnb \\
\hline abnb_rev & Number of Airbnb reviews per $\mathrm{km}^{2}$ & Inside Airbnb \\
\hline young_p & $\begin{array}{l}\text { Number of people aged between } 20-34 \text { years per } \\
\mathrm{km}^{2}\end{array}$ & American Community Survey \\
\hline pop_density & Population density of an NTA & American Community Survey \\
\hline ethnic_d & Score for ethnical diversity & American Community Survey \\
\hline black_p & Percentage of black population & American Community Survey \\
\hline nonUS & Percentage of non-US born residents & American Community Survey \\
\hline education & Percentage of bachelor's degree or higher & American Community Survey \\
\hline employee & $\begin{array}{l}\text { Ratio of the number of employees over the area's } \\
\text { population }\end{array}$ & American Community Survey \\
\hline income & Median household income & American Community Survey \\
\hline housing & Total housing units per $\mathrm{km} 2$ & American Community Survey \\
\hline house_own & Percentage of owner-occupied housing units & American Community Survey \\
\hline house_mortg & $\begin{array}{l}\text { Percentage of housing units with a mortgage } \\
\text { (owner-occupied) }\end{array}$ & American Community Survey \\
\hline rent & Median gross rent (occupied units paying rent) & American Community Survey \\
\hline POI & Number of attractions and entertainment places & OpenStreetMap \\
\hline
\end{tabular}

Source: edited by the authors.

\section{Statistical analysis}

In our study, we applied basic mathematical and statistical methods to answer the research questions raised in the introductory section. As the aim of the study was to measure which socio-economic factors influence the spatial spread of Airbnb, we initially analysed which of these factors associated with the New York City NTAs were correlated with Airbnb indicators. Nevertheless, at first, we eliminated those NTAs from our database where there were no housing units or the data was incomplete, such as parks or the vicinity of airports. Thus, our test sample size was reduced from 195 to 189 NTAs. In order to signal the nexuses between the selected indicators, we created a Pearson cross-correlation matrix using SPSS 23 statistical software and utilising the data indicated in Table 2. In addition to the correlation of specific indicators, it is practical to filter the partial effects as well. Thus, we applied

Regional Statistics, Vol. 7. No.1. 2017: 135-151; DOI: 10.15196/RS07108 
a multivariate linear regression model to reveal the relations between Airbnb supply and demand, and socio-economic indicators. Using our aggregated database, we compiled specific indicators that were utilised as input variables in our multivariate regression model. In the analysis, we strove to observe strict statistical rules (Dusek-Kotosz 2016, Kovács 2008); therefore, only those regression results were taken into consideration where there was a significant relationship between the dependent and independent variables and the explanatory power of the regression was greater than 0.5 . In addition, we also sought to filter multicollinearity between the input variables; thus, where the VIF value was above 5, the results were not taken into account.

\section{Findings and analysis}

By analysing Airbnb listings and the socio-economic features of the population in NTAs in New York City, the study presents a snapshot of the short-term accommodation sector of New York City and the factors affecting it. However, before analysing the spatiality and characteristics of the Airbnb units in New York City we have to differentiate three different types of rooms in Airbnb listings (entire home/apt, private room, shared room). As their name suggests, an entire home means that the host is not present in the unit during the guest's stay. A private room is a space within a host home and the host is present during the stay, but the guest has some private space (e.g. bedroom) and shares common space with others. The third type is when the guest and the host share the same living space, which represents the original model emphasised by the founders (Ke 2017, Samaan 2015). In all the major markets, where the short-term rental site is present, entire homes dominate Airbnb listings. In the US, according to the research of Ke (2017), 65.8 per cent of the listings are entire homes; however, our results highlight that in the case of New York City the share of these units shows lower values, as only 50 per cent of the listings are entire homes, 47 per cent is the share of private rooms, and shared rooms make up an almost negligible 3 per cent share of the market (Table 1). The descriptive statistics of Airbnb listings reflect quite similar values of entire homes and private rooms with the exception of price. Entire homes on the platform of Airbnb in New York City cost on average of twice as much as private rooms; however, the difference between the price of a private room and a shared room is not as significant at approximately $\$ 15$. The average availability of the listings is approximately 143 days for an entire home, while it is approximately 164 days for a private room. The numbers also suggest that in regard to entire homes, one host manages 1.36 listings, while in the case of private rooms the number is 2.13; however, there are several multiple-lister hosts operating more than two listings. Nevertheless, these numbers should be put into context, as according to Schneiderman (2014) multiple hosts represent only 6 per cent of Airbnb hosts, but

Regional Statistics, Vol. 7. No.1. 2017: 135-151; DOI: 10.15196/RS07108 
they dominate the platform and generate 37 per cent of all host revenues, receiving $\$ 168$ million. In addition, considering the entire home market, multiple-lister hosts earn 41 per cent of revenues (Cox-Slee 2016). These facts encourage critics to claim that a disproportionate amount of revenue is gained by 'commercial' hosts; incidentally, the vast majority of these listings are operated illegally by violating the MDL of New York City, ${ }^{1}$ disrupting neighbours, and displacing long-term residents.

Figure 1

Basic data on listings offered by Airbnb in New York City at borough and NTA level

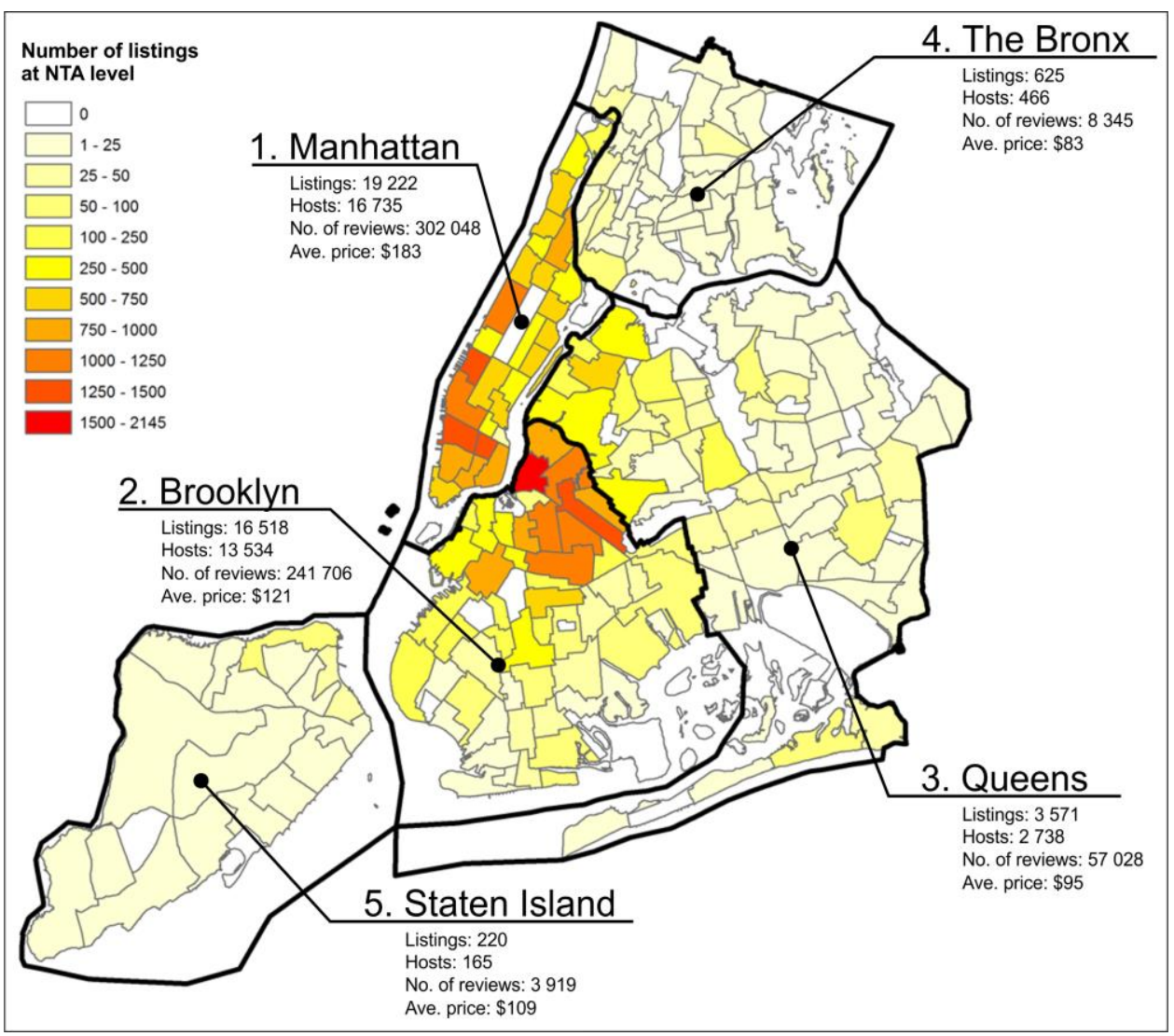

Source: based on http://insideairbnb.com/ data, edited by the authors.

The geographical distribution of Airbnb indicates the fact that the vast majority of the listings $(89 \%)$ are concentrated in a few neighbourhoods of Brooklyn and Manhattan (Figure 1), primarily in the southern part of Manhattan and northern

1 'The New York State Multiple Dwelling Law (the 'MDL') prohibits rentals of less than 30 days in 'Class A' multiple dwelling unless a permanent resident is present during the rental period' (Schneiderman 2014, p 18).

Regional Statistics, Vol. 7. No.1. 2017: 135-151; DOI: 10.15196/RS07108 
Brooklyn. These neighbourhoods are attractive to tourists and New York City residents as well because of the favourable access to public transport and jobs in Manhattan. Moreover, the study in Inside Airbnb (2017b) revealed that Airbnb activity overlaps with gentrification as the most popular Airbnb neighbourhoods are gentrifying or are already gentrified (e.g. Chelsea, Greenwich Village, Williamsburg, Greenpoint, Lower East Side, etc.). According to our dataset, from the 40,156 unique units about 16,000 hosts offered over 19,000 listings (47.8\%) in Manhattan and about 13,000 hosts offered more than 16,000 listings (41.1\%) in Brooklyn. These two boroughs account for most of the revenues generated by short-term rentals according to the New York General Attorneys' report (Schneiderman 2014). In Manhattan, the total host revenue between 2010 and 2014 exceeded $\$ 338$ million, while in Brooklyn it was $\$ 100$ million. By contrast, the other three boroughs yielded only $\$ 12.2$ million.

The number and spatial distribution of Airbnb listings and the revenues generated do not fully reflect the number of hosting events. However, to answer the research question raised in the introductory section and highlight where Airbnb customers actually go (Airbnb demand), we utilised the number of user reviews as a proxy. We applied this proxy as Fradkin et al. (2015) in their study had indicated that the number of reviews can be a good proxy for demand because the completion rate for reviews over the number of stays in an Airbnb accommodation is more than 70 per cent (Quattrone et al. 2016). Nevertheless, we also displayed the average Airbnb accommodation price in the New York NTAs, assuming that budget-conscious tourists may use cheaper Airbnb units (Figure 2).

The average Airbnb accommodation prices are more expensive in Manhattan and Brooklyn, while within these areas, the most expensive Airbnb units are located in the southern part of Manhattan (Midtown-Midtown South, SoHo-TriBeCa-Civic Center-Little Italy; West Village) and the north-western part of Brooklyn (Madison; Carroll Gardens-Columbia Street-Red Hook). In addition, the spatiality of the reviews indicates that use of Airbnb accommodations is less concentrated in a few neighbourhoods than in Airbnb listings. Although the vast majority of the reviews are given in the proximity of Manhattan and Brooklyn, the diffusion within these boroughs is more balanced. This signals that Airbnb users not only prefer the centrally located higher-priced accommodation but book in lower-priced neighbourhoods as well.

Regional Statistics, Vol. 7. No.1. 2017: 135-151; DOI: 10.15196/RS07108 
Figure 2

The price and the number of Airbnb reviews in New York City at NTA level
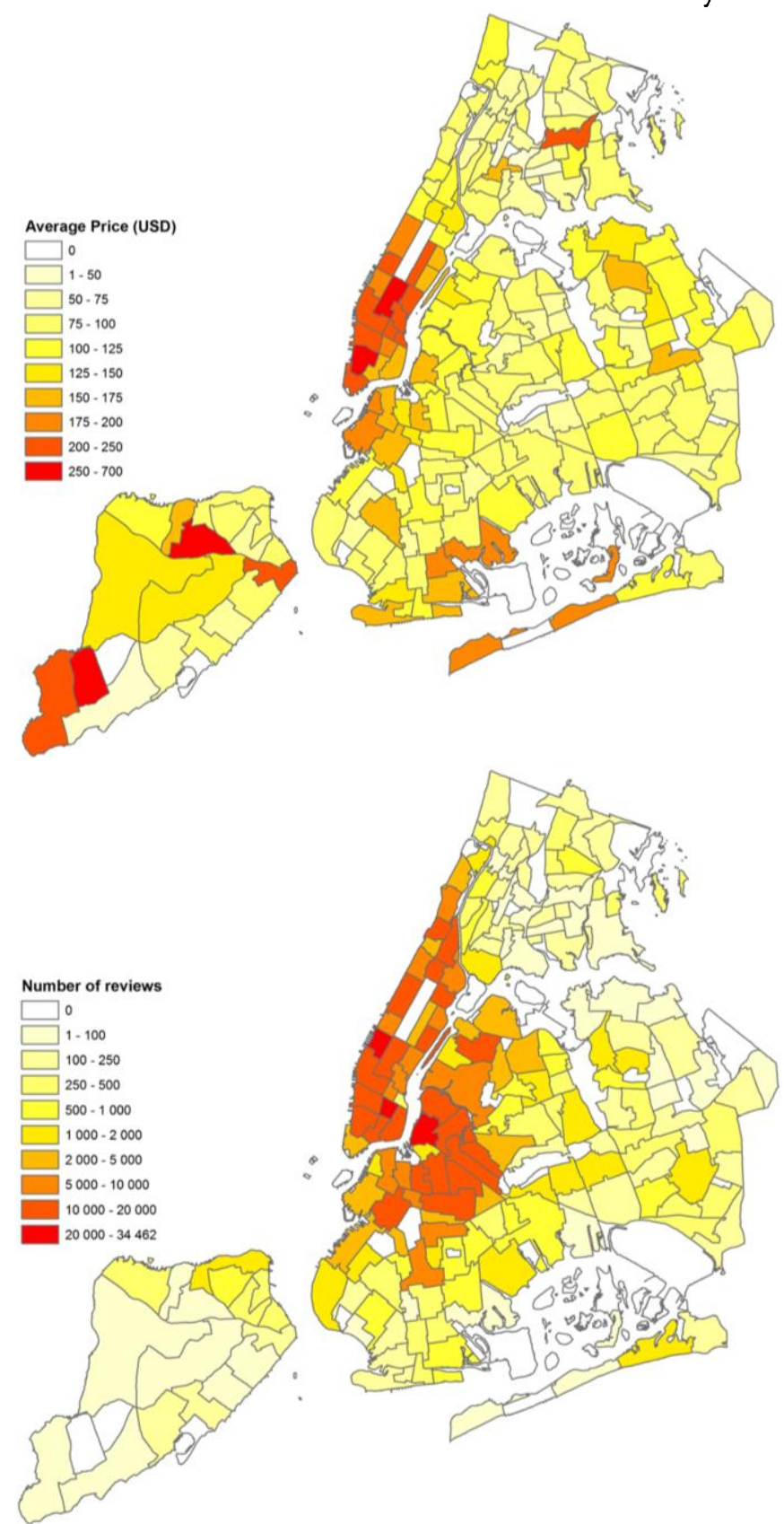

Source: based on http://insideairbnb.com/ data, edited by the authors.

Regional Statistics, Vol. 7. No.1. 2017: 135-151; DOI: 10.15196/RS07108 
In order to go beyond visual representation and descriptive statistics on Airbnb listings, we correlated our socio-economic indicators with Airbnb listings and compiled a correlation matrix (Figure 3). The results reflect that the number of Airbnb listings and reviews that concentrate in those areas have a population who are young, a significant number of housing units, and a notable POI supply. By contrast, the majority of the variables show moderate or weak positive covariance, while weak negative correlations are revealed between the Airbnb sector and the variables describing the ethnic structure, as well as the ownership structure of the housing market of the given areas. Regarding the third Airbnb indicator (price), it is apparent that price moderately correlates with education, household income, and the POI supply, while the other indicators show weak or negative values. Moreover, the matrix shows further covariance between the social and economic variables. These are strong positive correlations between high education, employment, and incomes, from which we could draw conclusions about the general development characteristics of the areas. In addition, these results may also reflect the partial distortion effects and their nexuses. Thus, to reveal the cause-effect relations and go into the details, we performed a multivariate linear regression analysis based on the number of Airbnb listings, reviews, and price.

Figure 3

Pearson cross-correlation matrix based on the independent variables of Table 2 with significance levels

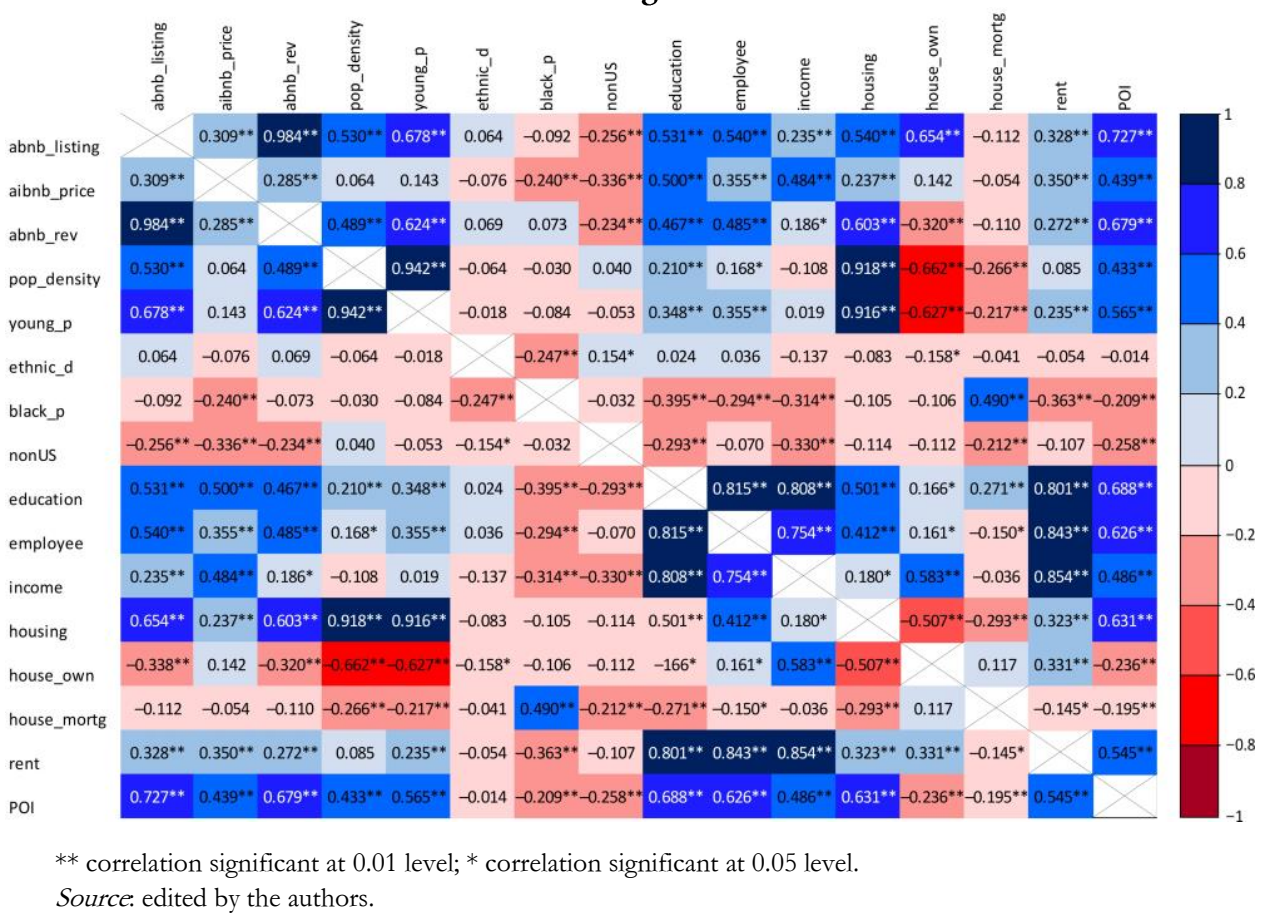

Regional Statistics, Vol. 7. No.1. 2017: 135-151; DOI: 10.15196/RS07108 
The multivariate linear regression analysis of Airbnb listings signals that the analysed indicators have almost a 70 per cent explanatory power of Airbnb supply (Table 3). The explanatory variables highlight that the proportion of young people, the employment rate, and the concentration of the POI supply positively affect the number of Airbnb listings, while the number of foreign-born residents and the rent negatively affect the supply. These results may indicate two phenomena. On the one hand, the model demonstrates that the spatial distribution of Airbnb supply is strongly related to the nearby attractions (POI supply) because within a given destination the accessibility of touristic attractions is essential. On the other hand, the analysis signals that the potential offered by Airbnb is popular among the youth population, who are highly educated and responsive to new technologies. In other words, gentrifiers tend to exploit the benefits of short-term rental. In addition, our model also highlights that positive correlation was normally outlined between Airbnb supply and the rental market; however, by filtering out the partial effects the relationship became negative, which directs attention to the methodological problems of traditional correlation analyses.

Table 3

\begin{tabular}{l|c|c|c}
\multicolumn{3}{c}{ Regression analysis of Airbnb listings } \\
\hline Independent Variables & $\begin{array}{c}\text { Standardized Beta } \\
\text { Coefficients }\end{array}$ & Sig. & VIF \\
\hline (Constant) & - & 0.002 & - \\
young_p & 0.367 & 0.000 & 1.525 \\
employee & 0.497 & 0.000 & 4.152 \\
POI & 0.391 & 0.000 & 2.340 \\
nonUS & -0.146 & 0.001 & 1.110 \\
rent & -0.407 & 0.000 & 3.583 \\
Dependent Variable: abnb_listing & Adjusted R Square: 0.698
\end{tabular}

Source: based on own calculations.

In analysis of the demand side (Table 4), the results show similar values, as the same independent variables significantly affect the concentration of the reviews as in the case of the supply side; however, the exploratory power was weaker at 61 per cent. The same indicators have a negative or positive impact on the demand side rather than on the supply side. This cause-effect relation between the two regressions might be traced back to the capitalist market mechanism and the balanced supply and demand approach.

We have conducted the same regression analysis considering Airbnb prices but there was no significant relation between the variables and the explanatory power did not reach the 0.3 regression value. Overall, the linear regression models of the socio-economic indicators only partly explain Airbnb supply, demand, and price.

Regional Statistics, Vol. 7. No.1. 2017: 135-151; DOI: 10.15196/RS07108 
This might be because social and economic processes are not necessarily linearly related to each other, therefore, in future, it would be advisable to analyse these processes by considering other approaches.

Table 4

\begin{tabular}{l|c|c|c}
\multicolumn{3}{c}{ Regression analysis of Airbnb reviews } \\
\hline Independent Variables & $\begin{array}{c}\text { Standardized Beta } \\
\text { Coefficients }\end{array}$ & Sig. & VIF \\
\hline (Constant) & - & 0.030 & - \\
young_p & 0.321 & 0.000 & 1.525 \\
employee & 0.490 & 0.000 & 4.153 \\
POI & 0.401 & 0.000 & 2.341 \\
nonUS & -0.129 & 0.008 & 1.110 \\
rent & -0.450 & 0.000 & 3.583 \\
Dependent Variable: abnb_rev & & Adjusted R Square: 0.609
\end{tabular}

Source: based on own calculations.

\section{Conclusions}

Owing to the heavy debates around the sharing economy and Airbnb, there is a rising interest in the spatial distribution of Airbnb listings in major cities and the factors affecting it; however, the determining role of socio-economic factors has received very little attention from researchers so far. Therefore, the present study seeks to fill this gap with a contribution that analyses the socio-economic factors influencing the spatial distribution of Airbnb listings in New York City.

The results indicated that Airbnb accommodations and the number of reviews are concentrated in those parts of the city that have a young population, a significant number of housing units, and a high number of points of interest. Our empirical findings also showed that there was no strong correlation between Airbnb price and the selected indicators but price moderately correlates with education, household income, and POI supply. Thus, the connection between gentrification and the growing Airbnb offers can be supported by the analysis. The regression analysis revealed that the socio-economic indicators have a 70 per cent explanatory power with respect to Airbnb supply highlighting that the proportion of young people, the employment rate, and the concentration of POI positively influences the number of Airbnb listings. The results signalled similar effects on the demand side with the exception that the explanatory power of the indicators was weaker at 61 per cent.

The connection between gentrification and the number of Airbnb listings indicates that the ongoing displacement processes in gentrifying neighbourhoods will continue in the future as short-term rentals increase the already elevated rent

Regional Statistics, Vol. 7. No.1. 2017: 135-151; DOI: 10.15196/RS07108 
gap in the affected neighbourhoods. This process especially threatens the predominantly black neighbourhoods, where gentrification has already started, but is in the early stage. In these neighbourhoods, despite the ethnic structure of the areas, the majority of the hosts are white (Inside Airbnb 2017b). As a result, they enjoy the benefits of Airbnb while blacks are more exposed to the negative impacts, and often face displacement. Airbnb intensifies the neighbourhood changes related to gentrification because it offers even more profitable investment opportunities. However, these processes could be understood more deeply through longitudinal studies analysing the changes in ethnic structure, the ethnic distribution of Airbnb hosts, and the dynamics of Airbnb offers.

Like other research, this study has some limitations. The first is that the analysis is limited to only one city (New York City), which may not allow us to generalise the results to other destinations. Second, the study presents only a snapshot of Airbnb offerings representing the situation in December 2016. Moreover, we have to note that while linear regression models have a certain explanatory power, these processes could be overwritten by complex and contradictory economic and social effects; they should be complemented by qualitative studies in the future. Considering these limitations, in future, we plan to conduct a longitudinal analysis and extend the number of cities included in the study, and also test our results on spatial autocorrelation. We hope that our study will encourage further research on this topic and raise further interest among geographers and researchers from other disciplines.

\section{REFERENCES}

AIRBNB (2017): About us https://www.airbnb.com/about/about-us (downloaded: August 2017)

ACS (2017): American Community Survey https://www1.nyc.gov/site/planning/datamaps/nyc-population/american-community-survey.page (downloaded: August 2017)

Azevedo, E. M.-WeYL, E. G. (2016): Matching markets in the digital age Science 352: 1056-1057.

Botsman, R.-Rogers, R. (2011): What's Mine Is Yours: The Rise of Collaborative Consumption Harper Business, New York.

ChOI, K-H.-JUnG, J.-RYU, S.-KIM, S-D.-YOON, S-M. (2015): The relationship between Airbnb and the hotel revenue: in the case of Korea Indian Journal of Science and Technology 26 (8): 1-8.

Cox, M.-Slee, T. (2016): How Airbnb's data hid the facts in New York City http://insideairbnb.com/reports/how-airbnbs-data-hid-the-facts-in-new-yorkcity.pdf (downloaded: August 2017)

Delgado-Medrano, H. M.-Lyon, K. (2016): Short Changing New York City - The impact of Airbnb on New York City's housing market BJH Advisors LLC. http://www.sharebetter.org/wp-

Regional Statistics, Vol. 7. No.1. 2017: 135-151; DOI: 10.15196/RS07108 
content/uploads/2016/06/NYCHousingReport_Final.pdf (downloaded: August 2017)

DudÁs, G.-Boros, L.-KovalcsiK, T.-KovalcsiK, B. (2017): The visualisation of the spatiality of Airbnb using 3-band raster representation Geographia Technica 12 (1): 23-30.

DuseK, T.-Kotosz, B. (2016): Területi Statisztika Akadémiai Kiadó, Budapest.

EDELMAN, B.-LUCA, M.-SVIRSKY, D. (2016): Racial discrimination in the sharing economy: Evidence from a field experiment HBS Working paper No. 16-069., Boston.

Einav, L.-Farronato, C.-Levin, J. (2016): Peer-to-Peer Markets The Annual Review of Economics 8: 615-635.

ERT, E.-Fleischer, A.-MAgEN, N. (2016): Trust and reputation in the sharing economy: The role of personal photos in Airbnb Tourism Management 55: 62-73.

EUROBAROMETER (2016): The use of collaborative platforms. Flash Eurobarometer: Vol. 438, Publication Office, Luxembourg. http://ec.europa.eu/COMMFrontOffice/ publicopinion/index.cfm/Survey/getSurveyDetail/instruments/FLASH/survey Ky/2112 (downloaded: August 2017)

Fradkin, A.-Grewal, E.-HoltZ, D.-PEARson, M. (2015): Bias and Reciprocity in Online reviews? Evidence from field experiments on Airbnb In: ROUGHGARDEN, T.Feldman, M.-Schwarz, M. EC 15 Proceedings of the Sixteenth ACM Conference on Economics and Computation pp. 641-641., Portland.

INSIDE AIRBNB (2017a): About http://insideairbnb.com/about.html (downloaded: August 2017)

Inside Airbnb (2017b): The face of Airbnb, New York City - Airbnb as a Racial Gentrification Tool http://brooklyndeep.org/wp-content/uploads/2017/03/ the-face-of-airbnb-nyc.pdf (downloaded August 2017)

Gutiérrez, J.-García-Palomares, J. C.-Romanillos, G.-SAlas-Olmedo, M. H. (2016): Airbnb in touristic cities: comparing spatial patterns of hotels and peerto-peer accommodations https://arxiv.org/ftp/arxiv/papers/1606/1606. 07138.pdf (downloaded: August 2017)

GuTTENTAG, D. (2015): Airbnb: disruptive innovation and the rise of an informal tourism accommodation sector Current Issues in Tourism 12 (18): 1192-1217.

HAMARI, J.-SJÖKLINT, M.-UKKONEN, A. (2016): The sharing economy: Why people participate in collaborative consumption. Journal of the Association for Information and Science and Technology 9 (67): 2047-2059.

IKKala, T.-LAmpinen, A. (2014): Defining the price of hospitality: networked hospitality exchange via Airbnb In: Fusseld, S.-LutTers, W.-Ringel MORRIS, M.REDDY, M. Proceedings of the companion publication of the $17^{\text {th }}$ ACM conference on Computer supported cooperative work \& social computing, pp. 173-176., Baltimore.

ING (2015): What mine is yours - for a price. Rapid growth tipped for the sharing economy https://www.ezonomics.com/ing_international_surveys/sharing_economy_201 5/ (downloaded: August 2017)

KAPlan, R. A.-NADler, M. L. (2015): Airbnb: a case study in occupancy regulation and taxation The University of Chicago Law Review Dialogue 82: 103-115.

Regional Statistics, Vol. 7. No.1. 2017: 135-151; DOI: 10.15196/RS07108 
KE, Q. (2017): Sharing means renting?: An entire marketplace analysis of Airbnb https://arxiv.org/pdf/1701.01645.pdf (downloaded: August 2017)

KOVÁCs, P. (2008): A multikollinearitás vizsgálata lineáris regressziós modellekben Statisztikai Szemle 86 (1): 38-67.

Malhotra, A.-Alstyne, M. V. (2014): The dark side of the sharing economy... and how to lighten it Communications of the ACM 57 (11): 24-27.

MCNamarA, B. (2015): Airbnb: A not-so-safe resting place Colorado Technology Law Journal 12: 149-169.

MeleO, L.-Romolini, A.-DE Marco, M. (2016): The sharing economy revolution and peer-to-peer online platforms. - The case of Airbnb In: BORANGIU, T.DragoiceA, M.-NóvOA, H. (eds.): Exploring Services Science. IESS 2016. Lecture Notes in Business Information Processing, vol. 247, pp. 561-570., Springer, Cham.

OSKAM, J. (2016): Airbnb or "Networked Hospitality Businesses": Between Innovation and Commercialization. A Research Agenda The proceedings of HONG KONG 2016: 2nd Global Tourism \& Hospitality Conference and 15th Asia Pacific Forum for Graduate Students Research in Tourism Vol. 1: pp. 499-510.

Oskam, J.-BoswijK, A. (2016): Airbnb: the future of networked hospitality businesses Journal of Tourism Futures 1 (2): 22-42.

PIZAM, A. (2014): Peer-to-peer travel: Blessing or blight? International Journal of Hospitality Management 38: 118-119.

Quattrone, G.-Proserpio, D.-Quercia, D.-Capra, L.-Musolesi, M. (2016): Who benefits from the "sharing" economy of Airbnb? In: BOURDEAU, J.- HENDLER, J. A.- Nkambou Nkambou, R.- Horrocks, I. (eds): Proceedings of the $25^{\text {th }}$ International Conference on World Wide Web pp. 1385-1394., Montreal.

SAMAAN, R. (2015): Airbnb, rising rent, and the housing crisis in Los Angeles http://www.laane.org/wp-content/uploads/2015/03/AirBnB-Final.pdf (downloaded: August 2017)

SCHNEIDERMAN, E. T. (2014): Airbnb in the city https://ag.ny.gov/pdfs/ AIRBNB\%20REPORT.pdf (downloaded: August 2017)

SCHOR, J. (2017): Does the Sharing Economy Increase Inequality Within the Eighty Percent? Findings from a Qualitative Study of Platform Providers http://www.bc.edu /content/dam/files/schools/cas_sites/sociology/pdf/SharingEconomyInequali ty.pdf (downloaded: August 2017)

Schor, J.-Fitzmaurice, C.-Carfagna, L. B.-AtTwood-Charles, W.-Poteat, E. D. (2016): Paradoxes of openness and distinction in the sharing economy Poetics 54: 66-81.

SLEE, T. (2016): What's yours is mine - Against the sharing economy OR Books, New York-London.

SMITH, A. (2016): Shared, collaborative and on-demand: The new digital economy http://www.pewinternet.org/2016/05/19/the-new-digital-economy/ (downloaded: August 2017)

Streitfeld, D. (2014): Airbnb listings mostly illegal, New York State contends https://www.nytimes.com/2014/10/16/business/airbnb-listings-mostly-illegalstate-contends.html?_r=0 (downloaded: August 2017)

Regional Statistics, Vol. 7. No.1. 2017: 135-151; DOI: 10.15196/RS07108 
Sundararajan, A. (2016): The Sharing Economy - The End and Rise of Crowd-Based Capitalism The MIT Press, Cambridge, Massachusetts, London.

WATERS, T.-BACH, V. (2016): Making the rent 2016 - Tenant conditions in New York City's changing neighbourhoods. Community Service Society - Fighting Poverty Strengthening New York http://lghttp.58547.nexcesscdn.net/803F44A/images / nycss/images/uploads/pubs/Making\%20the $\% 20$ Rent $\% 202016 \% 20$ -

$\% 20$ Final $\% 20$ as $\% 20$ of $\% 205 \% 2012 \% 2016 \% 20-\% 20$ web.pdf (downloaded: August 2017)

Zervas, G.-Proserpio, D.-BYers, J. (2015): A first look at online reputation on Airbnb, where every stay is above average https://ssrn.com/abstract $=2554500$ (downloaded: August 2017)

ZERVAs, G.-Proserpio, D.-BYERS, J. (2016): The rise of the sharing economy: Estimating the Impact os Airbnb on the hotel industry, Boston U. School of Management Research paper No. 2013-16. https://cs-people.bu.edu/dproserp/papers/ airbnb.pdf (downloaded: August 2017)

Regional Statistics, Vol. 7. No.1. 2017: 135-151; DOI: 10.15196/RS07108 